\title{
Information Technology In A New Normal Era
}

\section{Grace Lamudur Arta Sihombing ${ }^{1}$, Lamhot Martua Situmeang ${ }^{2}$, Rosmey Meriaty Br. Sormin ${ }^{3}$}

\author{
${ }^{1}$ Institut Agama Kristen Negeri Tarutung \\ ${ }^{2}$ Universitas Sisingamangaraja XII Tapanuli Utara \\ ${ }^{3}$ Education Authorities Of Kabupaten Tapanuli Utara
}

E-mail address : graceshbg@,iakntarutung.ac.id; E-mail address: lamhot@smrajaxii-unita.id ; E-mail address : meryati1978sormin@gmail.com

\begin{abstract}
Various efforts to prevent the spread of Covid-19 have been carried out, which resulted in the formation of a new normal life order for the community. Some of the adjustments include doing all activities from home, always washing hands, wearing a mask, and keeping a distance. New normal is also closely related to Information Technology (IT), where some activities are carried out through information technology assistance. Work From Home (WFH), online learning, online health consultations, and wedding receptions are conducted through a virtual room. However, in fact, there are still many who have not mastered and understood this, so this research explains the role of information technology, which is so important and quite influential in the fields of economy and business, education, health, religion, and the Internet of Things which is the core of current information technology.
\end{abstract}

Keywords: Information Technology (IT), New Normal

\section{INTRODUCTION}

Covid-19 pandemic changes the order of world society (Thomson, 2020). To prevent the spread of the widespread coronavirus outbreak, all countries in the world urge everyone to stay and do activities at home. Studying, working, praying is recommended at home. Because the SARS-cov-2 virus, which causes Covid-19, continues to threaten, death tolls due to this virus continue to grow. One way to survive in this situation is with a new lifestyle or new normal. New normal is a change in behavior to continue carrying out normal activities by implementing health protocols to prevent Covid-19 transmission. We must be able to adapt and develop ourselves to continue to survive in this situation. One of them is that we must be able to understand and use Information Technology (IT). With IT, we will get solutions and innovations to solve problems that will arise in the new normal life. Using technology to help humans continue their lives and face the threat of Covid-19.

The role of technology in the new normal era is very broad. Innovation and use of technology in the current era have significantly increased. Therefore, all of us must be able to master IT, especially in the fields of Education and Health. Work For Home (WFH) is one of the innovations that have emerged in today's work world, home study, online seminars or webinars, online health consultations, and many other innovations that use technology. Not only developed in this field, in the field of geography we know about GIS (Geographic Information System) with this technology, it is hoped that it can help map 
the areas affected by Covid-19. Based on the above problems, the purpose of this study is to determine the role of information technology, which is so important and quite influential in the fields of economy and business, education, health, religion in the new normal era.

\section{LITERATURE REVIEW}

\section{Information Technology In The Era Industry 4.0 Towards Industry 5.0}

Information technology is any technology that helps humans to create, change, store, convey information. Examples of information technology are computers, telephones, televisions, cellphones, and other electronic devices. Information technology is very influential in the industrial era of 4.0 because it relies on IT in the fields of economy, education, health, government, and others. Because information technology makes it easier for humans to produce, process data, and disseminate information. Information technology in this era is very fast so that the human workforce can turn to machine power with more guaranteed speed, accuracy, and success.

Industrial Evolution 4.0 collaborates with cyber technology and automation technology. The application concept is centered on the concept of automation carried out by technology without the need for human labor in the application process. This certainly adds to the value of efficiency in a work environment where time management is considered as something vital and very much needed by everyone and industry players. But now we are heading to Industry 5.0, an industrial concept created by Japan which was revealed by the Prime Minister on January 21, 2019, which explained that the rapid development of technology, including the presence of robots with intelligence that is considered to replace the role of humans. This is the background for the birth of Industry 5.0, which can be interpreted as a concept for a human-centered and technology-based society to support the fields of economy and business, education, health, religion, and many other things.

\section{RESEARCH METHODOLOGY}

This research uses qualitative research methods to determine the benefits arising from the application of information technology to support the fields of economy and business, education, health, religion. The author uses the document research method. Through this method, the author uses several reading sources in the form of books, magazine journals, and online access related to the title under study. The data processing and analysis technique in this research is qualitative data analysis, which is a non-statistical data processing technique.

\section{FINDING AND DISCUSSION}

\section{Information Technology in the Field of Economics and Business}

IT is a tool that provides the necessities for human survival. The development of science and technology is needed in the future and is applied in various aspects of life. For example, in the business sector, the banking sector has been enjoyed by humans in carrying out its activities. The benefits of technology in conducting business processes will have a positive impact on the development of the business itself. Businesses that utilize information technology can make it easier to communicate, promote, monitor processes, save on production and operational costs, simplify transactions, and make work systems more effective and efficient.

The Covid-19 pandemic has changed the pattern of people's behavior in making payment transactions towards a more secure contactless payment. The era of the digital economy has opened the widest 
opportunity for payment system innovation so that payment fintech was born as the main competitor of banks in providing payment transaction services.

The role of information technology in the economic and business fields includes the following:

1. E-banking is defined as the automatic delivery of bank services and products directly to customers via electronic, interactive communication channels. Channels of e-Banking that have been implemented by banks in Indonesia such as Phone Banking, Internet Banking, and SMS / m-Banking

2. E-Commerce: Electronic commerce (e-commerce) is the distribution, buying, selling, marketing of goods, and services through the system. Electronics such as the internet, television, and other computer networks. With an automatic inventory management system and an automatic data collection system.

The facilities above can be used by any person or business entity to facilitate transactions with anyone who can provide efficient and effective facilities.

\section{Information Technology in the Education Sector}

During the covid-19 pandemic, the education sector was one of the most affected. Students were prohibited from learning face-to-face, and online learning was enforced. Making Educators, students, and parents must be able to use technology. Most of the Schools or educational institutions do not yet have online learning media (e-learning platform) that is specifically for managing to learn. So that school leaders are overwhelmed in preparing for online learning.

Education in the new normal era brings many changes, especially in the process of integrating digital technology into the teaching and learning process. The use of this technology in education before the COVID-19 pandemic had occurred frequently, but it was not as massive as today. If digital technology was used as a supporting tool in the past, now digital technology is used as the main instrument. The importance of integrating digital technology and its benefits in educational activities can now be seen from how its features address the current needs of the education sector. Especially in the new normal era like this, both teachers and students depend on digital technology devices to connect with one another. Examples include video conferencing applications with a share screen feature to facilitate online classes, e-learning applications, google classrooms, academic sites, including devices that are compatible with the application to be used, namely smartphones, tablets, or laptops.

Digital technology also provides opportunities to learn more and also discover new things, such as accessing informal information from podcasts or documentary videos. Students can find new perspectives or ideas that are rarely found in scientific books. Keeping up with the development of digital technology also makes you more adaptive in this changing era.

\section{Information Technology in the Health Sector}

The Covid-19 pandemic has limited the movement of people to break the chain of spreading the virus. On the other hand, some people are still undergoing the treatment process. Therefore, various digital health service (Telemedicine) platforms are increasingly being used in the era of the Covid-19 pandemic. Many people can consult a doctor without having to go face-to-face, and patients can also buy drugs directly based on a digital prescription that the doctor sends after the consultation session. Telemedicine service itself is no longer a new thing in Indonesia. Several startups have offered telemedicine services, but the number of users is still low. Since the pandemic issue broke out in Indonesia, the use of telemedicine services has increased because of concerns about being exposed to Covid-19 if you visit the hospital in person.

In addition, the majority of hospitals have imposed service restrictions in order to break the Covid-19 chain. Therefore, the use of telemedicine services - where consultation with doctors is virtually possible, is predicted to continue to increase after the implementation of New Normal in Indonesia. Remote patient monitoring activities, previously used to monitor the patient's condition after being admitted to 
the hospital and reduce the likelihood of the patient returning to the hospital. However, during New Normal, remote patient monitoring will be more widely used to reduce the number of direct visits in terms of routine examinations and treatments. For example, when patients are discharged from the hospital, they will be provided with tools that can be used to track blood pressure levels, heart rates, body weight, oxygen saturation, and others. These activities will be combined with video teleconferencing so that health care between doctors and related patients can still be carried out even if it is a long distance.

The data generated by these patient monitoring tools can be integrated with the Hospital Management Information System (SIMRS). Thus, related doctors can more easily analyze patient progress based on the integration of this data, which includes patient medical records. Lintasarta Telemedicine helps the health industry In Indonesia in developing services. Through the Lintasarta Telemedicine service, it allows patients to have remote consultations with doctors and in the future can serve Tele-USG, TeleEKG, to Tele-Radiology. Lintasarta Telemedicine is also supported by a platform that can be integrated with various payment services via banks or e-wallets, SIMRS, insurance, delivery services, clinics, and TEMENIN, which is a telemedicine service owned by the Ministry of Health. Thus, hospitals, clinics, and patients can still provide and enjoy remote health services comfortably and safely.

\section{Information Technology in the Religious Sector}

The role and application of information technology in the religious field is also widely felt, one of which is the media for preaching. In the era of globalization, information and technological developments can be used as a medium to convey information to a wide audience. Examples of the application of IT to Christianity are made through the use of the internet, such as visual media, audio media, and audiovisual media for churches, ministries, broadcasting news, preaching the gospel, Christian literature, and so on.

\section{Internet Of Things in the New Normal Era}

Knowing the Internet of Things (IoT): The Key in the New Normal Era. As The Economist notes, one of the most obvious consequences of the current COVID-19 pandemic will be "the infusion of dataenabled services into ever more aspects of life." Digital transformation is becoming an even bigger 'obligation' for organizations today. The COVID-19 pandemic teaches us that without a strong technological basis, it is difficult to adapt to the new normal era.

You may often hear or already know about the Internet of Things (IoT). IoT is data interconnectivity using the internet. Often, there are many things that we don't realize that IoT has become a part of our daily lives.

Here are some ways the Internet of Things (IoT) can aid efforts during this critical time:

1. Accurate Location Tracking

As shipping becomes more important as people stay home to avoid viruses, customer expectations of on-time delivery are even higher than ever. By shifting to IoT-enabled devices, organizations can secure insights into delivery availability that will help them keep up to date with delivery estimates and periodic location updates while they await their packages.

1. Condition Monitoring

In addition to tracking delivery locations, the condition of the containers must be considered. By collecting, calculating, and sending updates on the environmental conditions of the container, IoT-enabled sensors can instill confidence that attached items are well looked after. This is especially important for suppliers of perishable or fragile goods, as containers move from supplier to distributor to customer.

3. Global Connectivity

Tracking and monitoring can only be achieved if the IoT device is connected to a global network and has the latest information. This means that everything we have done right now is attached 
to the Internet of Things. Which, of course, had made our activities very much easier even before this pandemic existed. It remains how we can and are able to understand and master the IoT to help us in the fields of business economics, education, health, and religion, etc.

\section{CONCLUSION AND FURTHER RESEARCH}

From the above discussion, information technology plays a very important role for all parties in various fields. Economics and business, education, health, religion, and other fields. With information technology, every job becomes more efficient and more effective. So that the new normal era provides several IT challenges and opportunities where the Covid-19 Pandemic has a large enough impact on people's lives. The activity of working from home, the school from home, worship from home, and other activities are slowly becoming a new trend in the current new normal phase. But with information technology, everything can be done and even more efficient.

Facing this, we must start to get used to working off-site, although it cannot be denied that this has its own constraints, especially on the network and system infrastructure. Even though the pandemic has not ended, several preparations for dealing with new norms must be implemented early on, namely:

1. Readiness of humans

The pandemic shifts the outlook and working habits of society to a large extent. If the maintenance of systems and facilities was historically carried out on-site, this work pattern is not always true today. As a consequence, human readiness to face change is a problem because it is humans who will be controlled in the end.

2. The Infrastructure

The IT Protection System has been tailored to the access needs of new users operating outside the premises. This need is what eventually becomes an obstacle, as the number of gates of access would raise the possibility of intrusion from cybercriminals.

3. Risk profile

Restricted mobilization between nations and face-to-face activities means that through digital channels, different activities and business processes must change. That means that both sides have to make adjustments to the organization's risk profile so that operations can continue. The digital transition must be started immediately by business people participating in the supply chain. For example, vendor-customer interactions would use digital applications, online orders, online payments, and training requirements.

4. Cutting expenses

Of course, improvements in operating practices will result in lower revenues. As a result, to keep the business competitive, many decision-makers are cutting costs. This is supported by PwC's COVID-19 CFO Pulse survey and Gartner's CFO survey, with at least 71 percent of CFOs trying to secure the liquidity and cash flow of the company. One of them is to remove company trips, minimize contractors, and avoid the recruiting of employees.

5. Profit from opportunities

With the new normal order, all levels of society are required to respond quickly to technology that brings new opportunities in the areas of digital payments, e-commerce, health care, and public care.

\section{REFERENCES}

Abdul Kadir \& Terra CH. (2003). Introduction to Information Technology. Yogyakarta: Andi Offset. Abdul Kadir \& Terra CH. (2003).Pengenalan Teknologi Informasi.Yogyakarta: Andi Offset. 
Budiman Haris. (2017) The Role of Information and Communication Technology in Education. AlTadzkiyyah: Journal of Islamic Education, Volume 8 No. I 2017. 31-43.

Bobby DePorter (1999). Quantum Learning. Jakarta.

Fatwa, A. (2020). Pemanfaatan Teknologi Pendidikan di Era New Normal. Indonesian Journal of Instructional Technology, 1(2).

Geger Riyanto. Information Technology, Innovation for the World of Education, in http://indrajayaadriand.wordpress.com/teknologi-informasi-inovasibagi world-education https://tekno.kompas.com/

Kaifa Geger Riyanto. Teknologi Informasi, Inovasi Bagi Dunia Pendidikan, dalam http://indrajayaadriand.wordpress.com/2007/07/14/teknologi-informasi-inovasibagi-duniapendidikan/, 22 Februari 2014.

Onno W. Purbo (2002). Teknologi e-Learning.

Martoredjo, N. T. Pandemi Covid-19: Ancaman atau Tentangan bagi Sektor Pendidikan?.

Thomson, B. (2020). The COVID-19 pandemic: A global natural experiment. Circulation.

https: //www.cnnindonesia .com / technology / 20200519152223-185-504966 / technology-trends-ineraSolusi-untuk-kenormalan-baru-new-normal

https://blog.lintasarta.net/article/industry-solutions/telemedicine-s-in-health-industry /

https://infokomputer.grid.id/read/122211311/menuju-new-normal-inilah-tChallenges-dan-peluang- tiafter-pandemic? page $=$ all 